\title{
ANALISIS ATAS PENERAPAN PRINSIP GOOD GOVERNANCE TERHADAP PROGRAM BANTUAN STIMULAN PERUMAHAN SWADAYA PADA DINAS PERUMAHAN KAWASANPERMUKIMAN DAN PERTANAHAN KABUPATEN HALMAHERA UTARA
}

\author{
Inggriani Nata ${ }^{1}$, Hendrik Manossoh $^{2}$, Lidia M. Mawikere $^{3}$ \\ ${ }^{1,2,3}$ Fakultas Ekonomi dan Bisnis, Jurusan Akuntansi, Universitas Sam Ratulangi, \\ J1. Kampus Bahu, Manado, 95115, Indonesia \\ E-mail : inggrianinata5@gmail.com
}

\begin{abstract}
Good Governance is a good governance and responsible management that is divided into several principles 5 (five) including Accountability, Transparency, Ekektif and Efesien, Responsiveness, Participation. The purpose of this study To know how the implementation of the principles of Good Governance in the program Self-help stimulant assistance. In this study the data used is qualitative, while for the data source using primary and secondary data and analytical methods used are descriptive analysis method. Based on the results of the study, it was concluded that the implementation of the Good Gavernance principle in the Self-Helping Housing Stimulus Assistance Program has been well executed.

Keywords: Government Accounting, Accountability, Transparency, Ekektif and Efficient, Responsiveness
\end{abstract}

\section{PENDAHULUAN}

Di Indonesia sendiri pemerintah juga memberi perhatian khusus pada area pembangunan. Berbagai macam fasilitas dan infrastruktur di kerjakan guna meningkatkan kesejahteraan masyarakat Indonesia. Salah satu bentuk perhatian dari pembangunan yang diberikan pemerintah adalah perhatian pada warga yang memiliki rumah tidak layak huni (RTLH), area ini menjadi salah satu perhatian serius pemerintah, dilihat dari tingkat perekonomian masyarakat di beberapa daerah di Indonesia yang rendah. Dengan demikian pemerintah berinisiatif untuk merencanakan program "Sejuta Rumah" dimana yang tercakup di dalamnya yaitu program BSPS (Bantuan Stimulan Perumahan Swadaya) guna meningkatkan taraf hidup setiap masyarakat yang ada. Program pembangunan tersebut tak hanya difokuskan pada satu daerah semata melainkan di fokuskan pada semua wilayah Republik Indonesia sebagai wujud penyemarataan pembangunan pada setiap daerah. Dalam hal ini Kabupaten Halmahera Utara Kecamatan Kao Utara desa Tunuo menjadi salah satu daerah yang menerima bantuan dari program tersebut.

Terjadinya krisis ekonomi disebabkan oleh tata kelola yang buruk (bad governance) pada sebagian besar pelaku ekonomi (publik dan swasta) hal ini seperti dikuatkan oleh pendapat Salah satu usaha memulihkan kondisi ekonomi, sosial dan politik adalah dengan mengembalikan kepercayaan rakyat kepada pemerintah dengan mencoba mewujudkan suatu pemerintahan yang bersih dan berwibawa atau yang dikenal dengan istilah good governance. Upaya ini juga didukung oleh banyak pihak baik pemerintah sendiri sebagai lembaga eksekutif, DPR sebagai lembaga legislatif, pers dan juga oleh lembaga-lembaga swadaya masyarakat.

Good governance adalah, penyelenggaraan pemerintahan kesinergiaan interaksi yang konstruktif diantara domain- domain (state, private sector and society).Untuk mencapai keberhasilan dari setiap program tentunya menjadi sangat penting untuk menilai sebuah program dalam menghasilkan pelayanan publik yang lebih baik. Selain itu dalam 
penyelenggaraanya aspek Good Governance menjadi bagian yang cukup penting untuk menilai bagaimana sebuah program berlangsung. Dengan melihat sisi akuntanbilitas dan keefektifan dan efisiensi dari pelaksanaan program tersebut.Daribeberapa prinsip good governance yang digunakan berbagai institusi pemerintahan, terlihat bahwa prinsip yang melandasi good governance sangat bervariasi dan disesuaikan dengan kondisi institusional.

Berdasarkan uraian diatas yang telah mencakup pembahasan secara tersirat serta terdapat pula fenomena-fenomena yang sedang terjadi yang berkaitan dengan persamaan good governance. Maka judul penelitian ini adalah "Analisis penerapan prinsip Good Governance terhadap bantuan stimulan perumahan swadya pada dinas perumahan kawasan permukiman dan pertahanan kabupaten tobelo Halmahera utara".

\section{TINJAUAN PUSTAKA}

\subsection{Konsep Dasar Akuntansi}

\subsubsection{Akuntansi}

Akuntansiadalah proses indentifikasi, pengumpulan, danpenyimpanandata serta proses pengembangan, pengukuran, dankomunikasi. SedangkanJofiyanto, dikutipolehWowerdan Widhiyani (2012) sistem informasi dapat dikatakan sebagai sistem dimana suatu organisai mempertemukan kebutuhan pengolahan data transaksiharian, mendukun goperasi, bersifatmanajerial, dan kegiatan strategi suatu organisasi dan menyediakan kepada pihak luar tertentu laporan-laporan yang diperlukan.

\subsection{Konsep Akuntansi Sektor Publik}

\subsubsection{Pengertian akuntansi sektor publik}

Akuntansi sektor publik merupakan aktivitas akuntansi yang dilakukan terhadap kejadian dan transaksi keungan organisasi sektor publik. karena organisasi sektor publik paling utama adalah pemerintah, maka akuntansi sektor publik juga dapat dinyatakan sebagai aktivitas akuntansi yang diterapkan pada pemerintahan, baik pemerintahan pusat maupun pemerintah daerah. (Siregar 2015: 3).

\subsubsection{Tipe Organisai Sektor Publik}

Pada dasarnya terdapat empat jenis tipe organisasi ( Mahsun: 2012).

1. Pure-profit organization

2. Quasi-profit organization

3. Quasi-Nonprofit Organization

4. Pure-nonprofit organization

\subsection{Standar Akuntansi Pemerintahan}

\subsubsection{Pengertian akuntansi pemerintahan}

Akuntansi pemerintahan memiliki kaitan yang erat dengan penerapan dan perlakukan akuntansi pada domain publik. Secara kelembangan dominan publik antara lain meliputi badan-badan pemerintahan, perusahaan milik Negara dan daerah ,yayasan ,organisasi masyarakat dan organisasi massa, lembaga swadaya masyarakat dan organisasi nirlaba (Halim, et, al, 2014: 14)

\subsubsection{Kerangka Konseptual Akuntansi Pemerintahan}

Dalam peraturan pemerintahan republic Indonesia nomor 71 tahun 2010 tentang standar akuntansi pemerintahan atau SAP, kerangka konseptual adalah konsep dasar penyusunan dan pengembangan standar akuntansi pemerintahan, dan merupakan acuan komite standar akuntansi pemerintahan, penyusunan laporan keungan, pemeriksa, dan pengguna laporan keungan dalam mencari pemecahan atas sesuatu masalah yang belum di atur dalam pernyataan standar akuntansi pemerintahan. 


\subsection{Good Governance}

\subsubsection{Pengertian Good Governance}

Kepemerintahan yang baik "Good governance"adalah kesepakatan menyangkut pengaturan Negara yang diciptakan bersama oleh pemerintah, masyarakat madani dan sektor swasta dimana kesepakatan tersebut mencakup pembentukan selunih mekanisme, proses, dan lembaga-lembaga dimana warga dan kelompok-kelompok masyarakat mengutarakan kepentingan mereka, menggunakan hak hukum, memenuhi kewajiban dan menjembatani perbedaan-perbedaan di antara mereka. (Masyarakat Transparansi Indonesia : 2012: 9).

\subsubsection{Prinsip-prinsip Good Governance}

Menurut United Nation Development Program (UNDP) prinsip-prinsip yang dikembangkan dalam Tata Kelola Pemerintahan yang Baik (Good Governance) adalah sebagai berikut :
1) Partisipasi
2.) Transparansi
3.) TanggungJawab.
4.) EfektifitasdanEfisiensi
5.) Akuntabilitas

Prinsip-prinsipdiatasmerupakansuatukarakteristik yang harus dipenuhi dalam hal pelaksanaan good governance yang berkaitan dengan control dan pengendalian, yakni pengendalian suatu pemerintahan yang baik agar cara dan penggunaan cara sungguh-sugguh mencapai hasil yang dikehendaki stakeholders.

\subsection{Penelitian Terdahulu}

Aty Uar tahun 2016, Judul skripsi Pengaruh Pelaksanaa Prinsip-prinsip Good Governance Terhadap Kinerja Pelyanan Publik Pada Badan Pertahanan Nasional (BPN) Kota Ambon. Tujuan Untuk mengetahuai bagaiman hubungan prinsip-prinsip goodgovernance dengan kinerja pelayan publikpada BPN Kota Ambon. Metode yang digunakan metode kuantitatif. Hasil penelitian menunjukan bahwa adahubungan yang signifikan antara pelaksanaan prinsip-prinsip goodgovernance dengan kinerja pelayanpublik pada BPN Kota Ambon sebesar $\mathrm{r}=0,77$ dan signifikan pada tingkatsignifikansi $95 \%(0.05)$.

\section{METODE PENELITIAN}

\subsection{Jenis Penelitian}

Jenis penelitian yang digunakan dalam penelitian ini adalah jenis kualitatif yaitu dengan tujuan untuk membahas permaslahan yang sifatnya menguraikan, menggambarkan, dan menerangkan suatu keadaan yang bertujuan untuk mendapatkan gambaran yang lebih jelas dan terperinci mengenai suatu keadaan tersebut berdasarkan data atau informasi yang telah di daptkan, kemudian dikumpulkan sehingga didapatkan informasi yang didapatkan informasi yang diperlukan untuk menganalisis masalah yang ada.

\subsection{Tempat dan Waktu Penelitian}

Tempat penelitian di laksanakan padaDinas Perumahan Kawasan Permukiman dan Pertanahan Kabupaten Tobelo Halmahera Utara.Waktu dalam penelitian ini di lakukan selama kurang lebih 1 bulan, yaitu pada bulan November sampai Desember 2017.

\subsection{Prosedur Penelitian}

1. Mengajukan permohonan penelitian dengan memasukan surat penelitian yang telah disetujui dari Fakultas Ekonimi dan Bisnis Universitas Samratulangi untuk melakukan penelitian pada Dinas Perumahan Permukiman dan Pertanahan Kabupaten Tobelo Halmahera Utara.

2. Melakukan wawancara dengan pihak Dinas Perumahan Kawasan Permukiman dan Pertanahan Kabupaten Tobelo Halmahera Utara pada program Bantuan Stimulan Perumahan Swadaya 
3. Mengumpulkan datayang diperlukan melalui wawancara dan dokumentasi

4. Membuat kesimpulan dan saran.

\subsection{Metode Pengumpulan Data}

1. Jenis Data

1. Data kuantitatif adalah data yang diukur dalam satuan skala angka menarik yang dapat di bedakan menjadi :

1) Data interval, yaitua data yang di ukur dengan jarak antara dua titik pada skala yang sudah di ketahui

2) Data rasio, yaitu data yang di ukur dengan suatau proporsi

2. Data kualitatif umumnya adalah data yang tidak dapat di ukur dalam skala numerik.

Dalam penelitian ini menggunakan data kualitatif. Data kualitatif adalah suatu metode penelitian yang dapat memberikan gamabaran jelas pada objek yang di teliti.

\section{Sumber Data}

Ada dua sumber data penelitian yang digunakan dalam pengumpulan data yaitu sebagai berikut :

a. Sumber data primer adalah data yang dikumpulkan dari sumber-sumber asil untuk tujuan tertentu. Dalam hal ini peneliti melakukan dengan cara pengambilan data kepada pihak yang bersangkutan, yang menerima bantuan stimulan perumahan swadaya yaitu berupa data sejara visi misi dan sruktur Oraganisasi dari dinas sampai dengan perangkat desa. Dalam hal ini yang menerima bantuan stimulant perumahan swadaya dan juga arsip atau dokumen-dokumen tentang bantuan stimulant perumahan swadaya.

b. Sumber data sekunder adalah data yang telah dikumpulkan oleh pihak lain yaitu melalui sumber-sumber dari jurnal atau dokumen-dokuemen tentang bantuan stimulant perumahan swadaya tersebut dalam penulisan ini menggunakan data kualitatif dan data primer.

\section{Teknik Pengumpulan Data}

Teknik yang digunakan oleh penulis dalam pengumpulan data untuk penelitian ini adalah dengan menggunakan cara sebagai berikut :

1. Wawancara

2. Observasi

3. Dokumentasi

\subsection{MetodeAnalisis}

Metode analisis yang digunakan dalam penulisan ini adalah metode Deskritif kualitatif,di mana metode ini membahas suatu permasalahan secara terperinci dengan menguraikan dan mengambarkan suatu keaadan secara sistematis,faktual,dan akurat mengenai fakta-fakta, sifat-sifat hubungan antara fenomena yang diselidiki sehingga dapat diartikan suatau kesimpulan untuk menjawab permasalahan yang ada.

\section{HASIL ANALISIS DAN PEMBAHASAN}

\subsection{Hasil Penelitian}

\subsubsection{Perencanaan Dana Bantuan Stimulan Perumahan Swadaya (BSPS)}

Awal Perencanaan Bantuan stimulan perumahan Swadaya (BSPS) Pada Kabupaten Halmahera Utara.Masyarakat sebagai pelaku utamadalam menerima bantuan dilihat dari masyarakat berpenghasilan rendah dan kondisi rumha yang tidak layak huni selanjutnya Bantuan Stimulan Perumahan Swadaya sebagai bantuan pemerintah untuk kesejahteraan masyarakatdari segi kualitas rumah dan kenyamanan adapun usaha yang harus di lakukan oleh masyarakat dalam menghuni rumah Bantuan Stimulan Perumahan Swadaya sebagai pengungkit keswadayaan masyarakat dalam mengerjakan rumah di lakukan secara swadaya 
dan kerja sama tim atau kelompok dalam rumah yang akan di bangun Gotong-royong dan berkelanjutandalam pembangunan ada pendampingan dari tenaga teknik yang di rekrut dari provinsi untuk ke kabupaten dalam hal ini kabupaten Halmahera Utara khususnya di desa Tunuo.

\subsubsection{Tahap perencanaan BSPS ( Bantuan Stimulan Perumahn Swadaya )}

Pada awal Tahun bulan januari-februari 2016 melewati beberapa tahapan sampai bias lolos dalam kategori masyarakat yang menerima bantuan rumah yang tidak layak huni, adapun tahapan peryaratan nya yaitu

1. WNI yang sudah berkeluarga;

2. memiliki atau menguasai tanah;

3. belum memiliki rumah, atau memiliki dan menempati rumah satu-satunya dengan kondisi tidak layak huni;

4. belum pernah memperoleh BSPS;

5. Berpenghasilan paling banyak senilai UMP setempat;

6. diutamakan yang telah memiliki keswadayaan dan berencana membangun atau meningkatkan kualitas rumahnya;

7. bersedia membentuk kelompok maks. 20 org.

\subsubsection{Pelaksanaan BSPS Bantuan Stimulan Perumahan Swadaya}

\subsubsection{Pengalokasian Dana Bantuan stimulan perumahan Swadaya}

Di kabupaten Halmahera Utara Kecamatan Kao utara di desa Tunuo jumlah hasil verifikasi data yang masuk $83 \mathrm{kk}$ yang di dalam nya terdiri dari PK.sedang $36 \mathrm{kk}$ dan $47 \mathrm{KK}$ PK. Bantuan yang diterima dalam bentuk barang kelokasi desa sesuai kebutuhan masingmasing. Jumlah Dana BSPS (bantuan stimulan perumahan swadaya) per kk di lakukan 2 kali dalam distribusi bahan yaitu pada bulan Maret dan Juli 2016 sesuai dengan tahapan kerja.

\subsubsection{Penyaluran dana Bantuan Stimulant Perumahan Swadaya (BSPS)}

Penyaluran dana ke masing-masing orang yang menerima bantuan berupa uang akan dalokasikan ke pihak ke 3 yaitu penyedia barang Dari penyedia barang mengirim bahan bangunan sesuai dengan kebutuhan pembangunan di masing-masing kelompok .

\subsubsection{Akuntabilitas}

Pada wawancara terdapat penjabaran dari responden yaitu akuntanbilitas pada program Bantuan Stimulan Perumhan Swadaya telah dilaksanakan sebagaimana semestinya program ini di buat. karena, setiap laporan keungan yang dibuat dalam program ini dapat dipertanggungjawabkan sesuai dengan peraturan perundang-undang yang berlaku.

\subsubsection{Transparansi}

Dari hal ini peneliti menarik kesimpulan bahwa Prinsip Transparansi dalam kegiatan program BSPS yang dipercayakan pada Dinas Perumahan kawasan permukiman dan pertanahan di Desa Tunuo telah dijalankan dengan baik seperti seharusnya di jalankan.

\subsubsection{Efektif dan Efisien}

Dari hasil wawancara peneliti mendapat sejumlah pendapat dan penjabaran yang di kemukakan responden. Responden menjelaskan bahwa program yang berlangsung termasuk pada kategori program yang tepat sasaran, hal ini dikarenakan Setiap proses kegiatan dan kelembagaan diarahkan untuk menghasilkan sesuatu yang benar-benar seusai dengan kebutuhan.

\subsubsection{Responsivitas}

Dari setiap jabaran yang didapatkan, peneliti menyimpulkan bahwa Prinsip Responsivitas telah di jalankan belum secara menyeluruh pada Dinas Perumahan kawasan permukiman dan pertanahan terkait dengan kegiatan Bantuan Stimulan Perumahan Swadaya yang dikerjakan. Hal ini disebabkan kurang memadainya informasi yang diberikan responden dalam memberikan penjelasan yang lebih akurat pada beberapa pertanyaan wawancara yang diberikan. 


\subsubsection{Partisipasi}

Dari hasil yang didapat dalam mewawancarai setiap responden menjelaskan bahwa partisipasi pada masyarakat di Desa Tunou dijalankan dengan baik. Partisipasi dari masyarakat dalam bentuk daya dan waktu dan pendapat menjadi hal yang penting. Pekerja lapangan pun memberdayakan setiap perangkat desa yang ada untuk menjadi salah satu saluran dimana masyarakat setempat dapat memberikan aspirasi mereka terhadap bagaimana berjalannya program ini.

\subsubsection{Akuntabilitas}

Akuntabilitas dipakai untuk mengukur atau menilai apakah dijalankan dengan baik.Dari prinsip ktersebut di atas dapat dipahami bahwa akuntabilitas berarti kewajiban untuk memberikan pertanggung-jawaban atau untuk menjawab dan menerangkan kinerja dan tindakan pemerintah kepadapihak yang memiliki hak atau wewenang untuk meminta pertanggung jawaban atau keterangan.

\subsubsection{Transparansi}

Prosedurdiberlakukanuntukmembuatpejabatpemerintahbertanggungjawabdanuntukme merangi korupsi bila rapat pemerintah dibuka kepada umum dan media massa, bila anggaran dan laporang keuangan diperiksa oleh siapa saja.

\subsubsection{EfektifdanEfisiensi}

Efektif dan Efisieni meupakan suatu program untuk mencapai tujuan menjadi tujuan atau sasaran yang telah ditentuhkan di dalam setiap organisasi,kegiatan ataupun program disebut efesieni apabila tercapai tujuan ataupun sasaran seperti yang telah di tentukan hal ini sesuai pendapat. Emerson salah satu prinsip yang penting yang tak dapat dipisahkan. Setiap kegiatan yang berlangsung memiliki hasil akhir yang perlu diukur untuk memperoleh kesimpulan baik tidaknya program atau kegiatan tersebut.

\subsubsection{Responsivitas}

Secara singkat dapat di katakana bahwa responsivitas ini mengukur daya tanggap dirokasi terhadap harapan, keinginan dan aspirasi, serta tuntutan masyarakat demikian di ungkapkan oleh Tangkilisan, responsivitas sangat diperlukan dalam pelyanan publik karena hal tersebut merupakan bukti kemampuan organisasi untuk menegenali kebutuhan masyarakat, menyusun agenda dan prioritas pelayanan publik karena hal tersebut merupakan bukti kempuan organisasi untuk mengenali kebutuhan masyarakat, menyusun agenda dan prioritas pelyanan serta mengembangkan program-program pelyanan publik sesuai denagan kebutuhan dan aspirasi masyarakat dan juga di ungkapkan olen Dilulio bahwa organisasi yang memiliki responsivistas rendah denagan sendirinya memiliki keinerja yang jelek juga, demikian yang diungkapkan Osborne.

\subsubsection{Partisipasi}

Partisipasi adalah prinsip bahwa setiap orang memiliki hak untuk terlibat dalam pengambilan keputusan disetiap kegiatan penyenggalaraan pemerintahan.Dari hasil penjabaran tersebut peneliti menyimpulkan bahwa prinsip Partisipasi telah diterapkan dengan baik di Dinas Perumahan kawsan permukiman dan pertanahan dalam program Bantuan Stimulan Perumahan Swaday pada Desa Tunuo.

\section{KESIMPULAN DAN SARAN}

\subsection{Kesimpulan}

Kesimpulan yang dapat ditarik dari penelitan ini yaitu:

\section{Akuntanbilitas}

Peneliti menarik kesimpulan bahwa prinsip Akuntanbilitas diterapkan dengan baik pada program Bantuan Stimulan Perumahan Swadaya hal ini didasarkan pada hasil wawancara yang di peroleh dari seorang reponden yang memaparkan bahwa program Bantuan Stimulan Perumahn Swadaya telah dilaksanakan sebagaimana semestinya program 
ini di buat. Peraturan yang dibuat tidak menitik beratkan pada suatu kelompok masyarakat semata, sehingga setiap masyarakat meperoleh hak yang sama dalam Program Bantuan Stimulan Perumahan Swadaya.

\section{Transparansi}

Peneliti menarik kesimpulan bahwa Prinsip Transparansi dalam kegiatan Program Bantuan Stimulan Perumahan Swadaya yang dipercayakan pada Dinas Perumahan kawasan permukiman dan pertanahan di Desa Tunuo telah dijalankan dengan kurang baik seperti seharusnya di jalankan.Hal ini dipaparkan dari hasil penelitian wawancara yang di peroleh dari responden yang mengungkapkan bahwa pada pelaksanaannya komunikasi yang terjadi antara staff di lapangan dengan masyarakat selaku penerima bantuan belumlah mencapai titik yang cukup memuaskan, hal ini disebabkan oleh beberapa faktor eksternal yang terjadi di lapangan, diantaranya jarak dan fasilitas. Jarak dan dukungan fasilitas menjadi aspek yang penting dalam keberhasilan komunikasi. Jarak fasilitator menempuh perjalanan menuju desa sering kali menjadi suatu hambatan suatu pengkordinasian suatu informasi. Sedangakan dukungan fasilitas seperti alat telekomunikasi dan daya penangkapan jaringan pada daerah tersebut mempengaruhi bagaimana suatu informasi dapat di komunikasikan dengan tepat.

\section{Efektif dan Efesien}

Peneliti mengambil kesimpulan bahwa Prinsip Efektif dan Efisien pada Program Bantuan Stimulan Perumahan Swadaya telah dijalankan sekalipun pada penerapannya masih ada hal-hal yang perlu diperbaiki untuk kedepannyaprogram yang berlangsung termasuk pada kategori program yang tepat sasaran. hal ini dikarenakan data yang dicantumkan seperti sebelumnya yang di paparkan pada tabel 4.1 merupakan data real yang diperoleh di lapangan dimana setiap warga yang di data adalah warga yang benar-benar memiliki kebutuhan untuk menjadi sasaran dari program Bantuan Stimulan Perumahan Swadaya ini.

\section{Responsivitas}

Peneliti menyimpulkan bahwa Prinsip Responsivitas telah di jalankan belum secara menyeluruh pada Dinas Perumahan kawasan permukiman dan pertanahan terkait dengan kegiatan Bantuan Stimulan Perumahan Swadaya yang dikerjakan. Hal ini disebabkan kurang memadainya informasi yang diberikan responden dalam memberikan penjelasan yang lebih akurat pada beberapa pertanyaan wawancara yang diberikan.

\section{Partisipasi}

Peneliti menyimpulkan bahwa prinsip Partisipasi telah diterapkan dengan baik di Dinas Perumahan kawasan permukiman dan pertanahan dalam Program BSPS di Desa Tunuo. Hal didukung oleh penjabaran yang diberikan oleh salah satu responden yang mengatakan bahwa partisipasi yang diberikan oleh pihak masyarakat desa selaku penerima bantuan program ini tergolong pada kategori partisipasi aktif, dengan hal ini setiap aktifitas yang dilakakuan terkait dengan program yang dilaksakan dapat berjalan dengan lebih baik.

\subsection{Saran}

1. Akuntanbilitas. Dengan diterapkannya dengan baik prinsip Akuntanbilitas pada Program BSPS di Desa Tunuo diharapkan agar Prinsip Akuntanbilitas dapat terus dijalankan bahkan ditingkatkan menjadi semakin lebih baik.

2. Transparansi. Dari kesimpulan yang diperoleh mengenai Prinsip Transparansi diharapkan seluruh jajaran yang bertugas pada di Dinas Perumahan Kawasan Permukiman dan Pertanahan yang menjalankan Program Bantuan Stimulan Perumahan Swadaya di Desa Tunuo dapat mengevaluasi kembali setiap program kerja yang dilakukan terkait Prinsip Transparansi ini agar dapat meningkatkan mutu dan pelayanan di Dinas Perumahan Kawasan Permukiman dan Pertanahan pada program-program berikutnya.

3. Efektif dan Efisieni. Penelitian ini diharapkan dapat meningkatkan pelayanan kinerja Dinas Perumahan Kawasan Permukiman dan Pertanahan dalam program-program berikutnya yang akan dicanangkan. Selain itu dari kesimpulan yang diperoleh Dinas 
Perumahan Kawasan Permukiman dan Pertanahan dapat mengevaluasi kembali seluruh rangkaian Program yang dikerjakan agar dapat meningkatkan Program kerjanya.

4. Responsivitas. Hasil penelitian ini diharapkan dapat menjadi sanggahan bahkan refrensi bagi Dinas Perumahan Kawasan Permukiman dan Pertanahan dalam rangka mengevaluasi program kerja untuk menghasilkan kinerja yang lebih baik.

5. Partisipasi. Diharapkan agar Dinas Perumahan Kawasan Permukiman dan Pertanahan dapat mempertahankan berlangsungnya penerapan Prinsip Transparansi pada Program Bantuan Stimulan Perumahan Swadaya di Desa Tunuo.

\section{DAFTAR PUSTAKA}

A Daim, Nuryanto, A, 2014. Hukum Administrasi Perbandingan Penyelesaian Maladministrasi oleh Ombudsman danPengadilan Tata Usaha Negara, LaksbangJusttitia, Surabaya.

Halim et, al, 2014. Akuntansi Sektor Publik, Pengertian Akuntansi Pemerintahan. PustakaBaru press

Harahap, Sofyan, Syafri, 2012. TeoriAkuntansiEdisiRevisi 2011. Jakarta : Raja GrafindoPersada.

Kieso, et, al, 2013. Intermediate Accounting,IFRS Edition: 2nd Edition. John Wiley \& sons Inc

Kuncoro, 2013. Metoderiset untuk bisnis\&Ekonomi .Bagaimana Meneliti\&danMenulis Tesis? Edisi 4.Penerbit Erlanga, Jakarta.

Mahmudi, 2013. Manajemen Kinerja SektorPublik, Yogyakarta : Unit Penerbit dan Percetakan Sekolah Tinggi Ilmu Manajemen YKPN.

Mahsun, Mohamad, Firma, sulistiyowati, heribetusdan A. Purwonugroho, 2012. AkuntansiSektorPublik. EdisiKetiga. BPFE, Yogjakarta

Mahmudi, 2012. Akuntansi Sektor Publik. PenerbitUllpress. Yogyakarta.

Marshall, B,Romney, dan Paul John Steinbart, 2015. SistemInformasiAkuntansi, Edisi 13. Salemba Empat: Jakarta.

Martini, Dwi,et, all, 2014. Akuntansi Keungan Menegah .Berbasis PSAK. Penerbit Selemba Empat. Jakarta.

Nana Syaodih, Sukmadinata, 2013. Metode Penelitian Pendidikan. Bandung PT Remaja Rosdakarya.

Nordiawan, Wiratna, 2012. Akuntansi Sektor Publik, Pengertian AkuntansiPemerintahan. Pustaka Baru Press

Nordiawan, Hartianti, 2012. Akuntansi Sektor Publik (2ed). Jakarta :Salembah Empat.

Pontoh, 2013. Akuntansi :Konsep dan Aplikasi. Halaman Moeka. Jakarta. 